\title{
Bacillus larvae: its Gultivation in vitro and its Growth in vivo
}

\author{
By L. BAILEY AND D. C. LEE \\ Rothamsted Experimental Station, Harpenden, Hertfordshire
}

(Received 6 April 1962)

\begin{abstract}
SUMMARY
Spores of Bacillus larvae White germinate and make initial vegetative growth best in a limited range of low redox potentials, but later growth and sporulation occur best aerobically. Different media needed for best results with each phase of development of the bacillus are described. Spores of $\boldsymbol{B}$. larvae germinate in the mid-gut contents of honey-bee larvae up to 2 days old. The vegetative forms then migrate and become closely applied to, but do not penetrate, the mid-gut epithelium. Most organisms seem to be voided with the contents of the intestine when an infected larva defaecates shortly before it pupates. A few organisms are presumably left in the intestine and probably invade the tissues of the larva as it pupates.
\end{abstract}

\section{INTRODUCTION}

Bacillus larvae White does not germinate or sporulate on ordinary bacteriological media. Extract of larval honey-bees (White, 1907), unheated egg yolk (White, 1920) and egg yolk + yeast + carrot-extract + peptone (Sturtevant, 1932) are usually fairly suitable media but only when inoculated with many million spores (Tarr, 1937). A medium containing glucose, peptone and thiamine with trace elements (Lochhead, 1942) is sometimes satisfactory and becomes more reliable with added soluble starch or after treatment with activated charcoal (Foster, Hardwick \& Guirard, 1950). Good sporulation has been obtained on agar containing extract of pollen (Smith, Beck \& Anderson, 1949) and on agar containing yeast extract + soluble starch (Foster et al. 1950); good germination has been obtained below the surface of semi-solid agar of other media (White, 1920; Lochhead, 1933).

Rods, presumed to be vegetative forms of Bacillus larvae, appear in the intestines of 1 to 2-day-old larval honey-bees within $24 \mathrm{hr}$. of their food being inoculated with spores (Woodrow \& Holst, 1942; Kitaoka, Yajima \& Azuma, 1959). The rods are thought not to multiply much in the intestine (Maassen, 1908; Holst, 1946) but to invade the haemolymph where they multiply greatly (Jaeckel, 1930). It is not clear, however, when they leave the gut. Rods have been found in the haemolymph of 2or 3-day larvae (Jaeckel, 1930) but, judging by the accounts, the larvae, which were artificially and probably very heavily infected, seem to have been moribund, perhaps dead, when examined. (Most larvae die from natural infection immediately before or just after they pupate, when they are about 9 days old and have been sealed in their honeycomb cells.) Other workers have found very few rods in larvae between 3 and 6 days after these had been infected when 0-1 day old, and none when the larvae had become 7-9 days old, yet all remaining infected larvae became diseased when 13-14 days old (Kitaoka et al. 1959). Larvae older than 2 days are 
immune to infection (by $10^{5}$ spores); larvae younger than $24 \mathrm{hr}$. are most susceptible and ten or fewer spores then suffice to cause disease (Woodrow, 1942; Hitchcock, 1958). Larvae 4-5 days old are usually immune, but inoculation with very many spores (about $10^{7}$ ) may infect them (Sturtevant, 1932).

The present paper gives results obtained in vitro with modifications of a medium based on one which proved successful for Streptococcus pluton (Bailey, 1957; Bailey $\&$ Gibbs, 1962) a fastidious pathogen that grows in the same natural environment (intestinal contents of honey-bee larvae) as that in which Bacillus larvae starts its life cycle. Observations are given, in the light of these results, on the natural growth of $B$. larvae.

\section{METHODS}

Spores of Bacillus larvae were obtained from the dried remains (scales) of larvae which had died of American foulbrood. There were about $2.5 \times 10^{9} \mathrm{spores} / \mathrm{scale}$ but usually no other micro-organisms. Scales were picked out of honeycombs of diseased brood and suitable inocula prepared by extracting them with sterile water.

A basal medium of $1 \%(\mathrm{w} / \mathrm{v})$ yeast extract (Difco) $+1 \%(\mathrm{w} / \mathrm{v})$ soluble starch was used and the media to be tested were made up from it as follows:

(1) basal + 0.1 $\mathrm{m}-\mathrm{KH}_{2} \mathrm{PO}_{4} ;$ (2) basal +0.1 $\mathrm{m}-\mathrm{KH}_{2} \mathrm{PO}_{4}+1 \%(\mathrm{w} / \mathrm{v})$ glucose; (3) basal $+0.1 \mathrm{~m}-\mathrm{KH}_{2} \mathrm{PO}_{4}+1 \%$ glucose autoclaved separately; (4) basal $+0.01 \mathrm{~m}-$ $\mathrm{KH}_{2} \mathrm{PO}_{4} ;(5)$ basal $+0.01 \mathrm{M}-\mathrm{KH}_{2} \mathrm{PO}_{4}+1 \%(\mathrm{w} / \mathrm{v})$ glucose $;(6)$ basal $+0.01 \mathrm{M}-\mathrm{KH}_{2} \mathrm{PO}_{4}+$ $1 \%(w / v)$ glucose autoclaved separately.

Media were adjusted to $\mathrm{pH}$ 6.6 with $\mathrm{KOH}$ and autoclaved in closed screw-capped bottles at $116^{\circ}$ for $20 \mathrm{~min}$. Unless stated otherwise, inoculated media were incubated aerobically at $34^{\circ}$.

The stabilities of the redox potentials in sterile deep agars of these media were deduced by observing the reduction of methylene blue $(0.2 \mathrm{mg} . / 100 \mathrm{ml}$. medium $)$ in them while they were incubated for several days.

Numbers of organisms were counted in a Helber counting chamber; the proportions of spores to vegetative forms in cultures were found by differentially staining microscope preparations by the malachite green-mercurochrome method of Wynne (1948).

Suitable larvae for infection were obtained by confining the queen of a colony to a comb in a metal cage with slots through which the worker bees could pass but the queen could not. The cage was placed in the brood-nest of the colony and, after $24 \mathrm{hr}$., the queen was released. After a further 3 days the comb usually contained many hundreds of larvae $\mathbf{0 - 2 4} \mathrm{hr}$. old. Individual larvae were identified with coordinates by using a calibrated frame. The food surrounding identified larvae was inoculated by means of a microsyringe with $0.4 \mu \mathrm{l}$. of a suspension of spores of Bacillus larvae in a $25 \%(\mathrm{v} / \mathrm{v})$ solution of honey in water. Each larva received about $10^{6}$ spores. Larvae to be examined histologically were fixed in Bouin, sectioned and stained with Heidenhain's haematoxylin. Larvae not taken for histological or other work were left in the colony until sealed in their cells. The comb was then removed and incubated at $341^{\circ}$ for 7 days, after which all larvae were examined and dead ones examined for spores of $B$. larvae. 


\section{RESULTS}

Semi-solid agar was best for germination of spores; medium 5 (yeast extract + soluble starch $+0.01 \mathrm{M}-\mathrm{KH}_{2} \mathrm{PO}_{4}+1 \%$ glucose) was clearly superior to the rest: almost every spore germinated in the zone where growth began (Table 1). When there were very few spores/ml. medium, many satellite colonies formed round those colonies which first appeared. Growth appeared on the surface of semi-solid agar after a further 1 or 2 days, the longest time being taken in agars with fewest spores. Growth below the surface then dwindled in media 2 and 5 and vanished in the others, the agar becoming quite clear again. These tests were repeated on many occasions and gave entirely consistent results.

Table 1. Germination of spores of Bacillus larvae in semi-solid agar

\begin{tabular}{|c|c|c|c|c|c|c|c|c|c|c|c|}
\hline \multirow{2}{*}{$\begin{array}{c}\text { Medium } \\
\text { no. }\end{array}$} & \multirow{2}{*}{$\begin{array}{l}\text { Incubation } \\
\text { period } \\
\text { (days) }\end{array}$} & \multicolumn{9}{|c|}{$\begin{array}{l}\text { Size of inoculum } \\
\text { (approx. log. spores/ml. } \\
\text { medium) }\end{array}$} & \multirow[b]{2}{*}{ Remarks } \\
\hline & & 8 & 7 & 6 & 5 & 4 & 3 & 2 & 1 & 0 & \\
\hline 1 & $\begin{array}{l}2 \\
3\end{array}$ & $\begin{array}{l}+ \\
+\end{array}$ & - & - & - & $\overrightarrow{-}$ & - & - & - & - & Growth began at various depths \\
\hline 2 & $\begin{array}{l}\mathbf{2} \\
\mathbf{3}\end{array}$ & $\begin{array}{l}+ \\
+\end{array}$ & $\bar{t}$ & $\overline{+}$ & $\overline{+}$ & $\overline{+}$ & $\overline{+}$ & - & - & - & $\begin{array}{l}\text { Growth began between } 3 \text { and } 5 \\
\text { mm. below the surface and was } \\
\text { typically in two very narrow } \\
\text { bands }\end{array}$ \\
\hline $\mathbf{3}$ & $\begin{array}{l}\mathbf{2} \\
\mathbf{3}\end{array}$ & $\begin{array}{l}+ \\
+\end{array}$ & - & - & - & - & $\overline{-}$ & - & - & - & As for medium 1 \\
\hline 4 & $\begin{array}{l}2 \\
3\end{array}$ & $\begin{array}{l}+ \\
+\end{array}$ & $\begin{array}{l}+ \\
+\end{array}$ & - & - & - & - & - & - & - & As for medium 1 \\
\hline 5 & $\begin{array}{l}\mathbf{2} \\
\mathbf{3}\end{array}$ & $\begin{array}{l}+ \\
+\end{array}$ & $\begin{array}{l}+ \\
+\end{array}$ & $\begin{array}{l}+ \\
+\end{array}$ & $\begin{array}{l}+ \\
+\end{array}$ & $\begin{array}{l}+ \\
+\end{array}$ & $\begin{array}{l}+ \\
+\end{array}$ & + & $\overline{+}$ & + & $\begin{array}{l}\text { Growth began between } 5 \text { and } 10 \\
\text { mm. below the surface. Two } \\
\text { weakly differentiated bands of } \\
\text { optimum growth sometimes } \\
\text { seen }\end{array}$ \\
\hline 6 & $\begin{array}{l}\mathbf{2} \\
\mathbf{3}\end{array}$ & $\begin{array}{l}+ \\
+\end{array}$ & $\begin{array}{l}+ \\
+\end{array}$ & - & - & - & $\frac{-}{-}$ & - & - & - & As for medium 1 \\
\hline
\end{tabular}

Germination was fairly good in deep solid agar, particularly with concentrated inocula. In medium 2 germination and initial vegetative growth were restricted to a narrow zone that was typically in two very narrow horizontal bands. In media 3, 4, 5 and 6 growth often extended from the surface to the bottom of the tube with a wide zone free from growth between 1 and $2 \mathrm{~cm}$. below the surface. The vegetative growth, which appeared after about 4 days, disappeared after another day or two except on or near the surface.

Spores usually failed to germinate in streaks or pour-plates. Most success was with media 3,5 or 6 . When growth appeared in pour-plates it was at first very patchy and few colonies grew on the surface. Inocula of many million spores were necessary to start growth.

Attempts to subcultivate from deep solid agar to the surface of agar of any kind almost always failed, but vegetative growth was readily transferred from the surface or subsurface of semi-solid agar to the surface of agars of most of the media 
(Table 2). Vegetative growth could be transferred readily from semi-solid agar for at least 8 days after it had appeared.

Sporulation occurred on the surface of agar or in semi-solid agar of all media except no. 2 or nutrient agar (Table 2), and was best on media 1 or 4 , on which sporulation ceased about 10 days after growth began.

Slopes of $10 \mathrm{ml}$. of medium 4 yielded $2 \cdot 7 \times 10^{8}$ spores (20 observations; standard error of mean $\left.=0 \cdot 4 \times 10^{8}\right)$. The average ratio of spores to vegetative forms which developed ultimately in medium 4 was about $1: 1$. This ratio was increased significantly $(P<0.02)$ to about $2: 1$ when the medium contained $10 \%(\mathrm{v} / \mathrm{v})$ of an aqueous extract of pollen $(10 \%, w / w)$, freshly collected by bees.

Table 2. Growth and sporulation of Bacillus larvae on agar

$\begin{array}{cccccc}\begin{array}{c}\text { Medium } \\ \text { no. }\end{array} & \overbrace{\begin{array}{c}\text { Transferred from } \\ \text { semi-solid agar }\end{array}}^{\text {Growth (1-2 days) }} & \begin{array}{c}\text { Transferred from } \\ \text { surface growth }\end{array} & \overbrace{\begin{array}{c}\text { After 4 } \\ \text { days }\end{array}}^{\text {Sporulation }} & \begin{array}{c}\text { After 6 } \\ \text { days }\end{array} \\ \mathbf{1} & + & + & ++ & ++ \\ \mathbf{3} & - & ++ & - & - \\ \mathbf{4} & ++ & + & + & + \\ \mathbf{5} & + & ++ & - & + \\ \mathbf{6} & \pm & ++ & - & \pm \\ \begin{array}{c}\text { Nutrient agar } \\ \text { (Oxoid No. 2) }\end{array} & ++ & \pm & \pm & - & -\end{array}$

$-=$ growth/sporulation never occurred; $\pm=$ growth/sporulation varied between nil and some; $+=$ growth/sporulation always occurred; $++=$ growth/sporulation always plentiful.

Table 3. The numbers of honey-bee larvae which suffered various fates after the food of each had been inoculated with $10^{6}$ spores of Bacillus larvae

\section{Fate of larvae}

Pupated normally

Ejected before being sealed in their cells

Died after being sealed in their cells

Taken when 2-3 days old and examined histologically

Taken when 4-5 days old and examined histologically

Taken when 7-8 days old and examined histologically
Age (days) of larvae when their food was inoculated

$\begin{array}{cccc}0-1 & 1-2 & 2-3 & 3-4 \\ 3 & 15 & 36 & 52 \\ 101 & 39 & 14 & 26\end{array}$

$11(11)^{*} \quad 7(7)^{*} \quad 000$

$$
5(5) \dagger
$$

$16(13) \dagger$

$13(6) \dagger$

$10(0) \dagger$

$10(0) \dagger$

$10(0) \dagger$

* Number in parentheses = larvae with spores of $B$. larvae in body tissues.

$\dagger$ Number in parentheses = larvae containing vegetative forms of $B$. larvae (when present vegetative forms were in the gut contents only).

Results identical with all those above were obtained with added $\mathrm{CO}_{2}$ (about 5 or $10 \%, \mathrm{v} / \mathrm{v}$ ) in the atmosphere and with media that contained sodium phosphate instead of potassium phosphate. Growth did not occur anaerobically (in McIntosh and Fildes jars), with or without $\mathrm{CO}_{2}$. 
Methylene blue was abruptly reduced below a boundary that stayed about $8 \mathrm{~mm}$. deep for many days in medium 2 agar. It was less abruptly reduced below a boundary that stayed about $20 \mathrm{~mm}$. deep in medium 5 agar, rather gradually reduced below unstable boundaries about 25-35 mm. deep in agars of media 3 and 6, and was not reduced, or only temporarily so below about 35-45 mm., in agars of media 1 and 4 .

Spores germinated and produced detectable vegetative growth only in larvae younger than 2 days (Table 3). Histological sections showed that vegetative rods were dispersed evenly throughout the intestinal contents of these young infected larvae. By the time larvae were 4-5 days old, the rods were mostly in a thin layer against the epithelium (Pl. 1, fig. 1). Rods were frequently seen interspaced among and aligned with the hairs of the brush border of the epithelial cells ( $\mathrm{Pl}$. 1, fig. 2), but no rod was ever seen to have penetrated the tissue. There is little doubt, however, that many or most of these larvae would have been killed by the infection had they been left to pupate (Table $\mathbf{3}$ ).

Some larvae which had been infected between the ages of 1 and 2 days were removed from the comb when 5 days old and incubated in dishes at $34^{\circ}$. They spun cocoons and voided their intestinal contents normally, and their faeces contained very many rods, apparently of Bacillus larvae. Most of these larvae then died and spores formed in them.

\section{DISCUSSION}

The banded growth of Bacillus larvae in deep agar resembled that of Streptococcus pluton in the same media (Bailey \& Gibbs, 1962) but was slightly nearer the surface. The redox potentials in medium 2 agar, in which the very narrow bands of growth formed, were evidently very stable and it seems that a narrow range of potential, slightly above zero, is required for spores of $B$. larvae to germinate. Medium 5 agar is most suitable for germination of spores of $B$. larvae perhaps because it has a fairly stable wide range of suitable redox potential. When there was double-banded growth, the medium close to the band that first appeared may have become too reduced for the spores in it to germinate. The necessary redox potential presumably occurred again where this reduction was balanced by oxidation from above so that further spores germinated.

Growth soon became limited to the surface or subsurface regions of deep agar of all media, and particularly of those with weakly poised Eh values, probably because the deeper regions became too reduced by the vegetative growth. Organisms migrated through semi-solid agar, hence the satellite colonies and, perhaps, the eventual surface growth on semi-solid agar that had been inoculated with very few spores; but the disappearance of vegetative growth from the deepest regions may have been mostly by autolysis.

Vegetative growth transferred poorly from semi-solid agar to the surface of agars of media 2 and 5, particularly medium 2, probably because the surface of these media becomes very oxidized. (There is evidence that this sometimes happens with medium 2 to make it unsatisfactory for Streptococcus pluton; see Bailey \& Gibbs, 1962). Vegetative forms of Bacillus larvae grew well when transferred to the surface of the other media, probably because they could reduce the weakly poised redox potential of the agar sufficiently to continue their growth. Once vigorous growth was established subcultivation to the surface of any of the media became possible. 
The results obtained by previous workers with a range of complex media for $B$. larvae probably depended largely on the redox potentials in the media rather than on their nutritive value and ionic composition.

Adding pollen extract to medium 4 increased sporulation much less than observed by Smith et al. (1949), who used a similar medium + Neopeptone (Difco), so that it can be inferred that pollen extract not only improves sporulation but counteracts a detrimental effect of Neopeptone.

The behaviour of Bacillus larvae in nature may be interpreted in terms of its characteristics in vitro. Spores germinate and multiplication begins in vitro within a narrow range of redox potentials. Such conditions may occur only in the young larvae and account for their susceptibility. Old larvae, because of their greatly increased size, may have a lower Eh value in their gut contents, or it may decrease quicker when vegetative $B$. larvae is present, than in young larvae: this could account for the failure either of spores to germinate or of the aerophilic vegetative forms to migrate to the epithelium in old larvae. (It would also account for the ability of Streptococcus pluton, which needs a microaerobic to anaerobic environment, to continue its growth in the gut contents of larvae of any age; see Bailey \& Gibbs, 1962.) The vegetative forms of $B$. larvae that reached the gut epithelium were unable to penetrate the tissues, at least of the larvae that were not ejected by nurse bees, and most of them were probably voided in the faeces when the larvae pupated. These vegetative forms are of no further consequence because they cannot infect more larvae (Tarr, 1937) even if they could survive desiccation in the larval faeces. A few organisms presumably remain in the gut and invade the aerobic tissues where they can multiply and sporulate, probably when the gut epithelium changes to the adult type during pupation.

Bacillus larvae may have penetrated the tissues of the many young larvae that were ejected shortly after they had been infected (Table 3 ). If this always happened, however, $\boldsymbol{B}$. larvae could not survive because the larvae were ejected before they had begun to decompose and spores would not have formed.

\section{REFERENCES}

Barley, L. (1957). The isolation and cultural characteristics of Streptococcus pluton (Bacillus pluton White) and further observations on Bacterium eurydice. J. gen. Microbiol. $17,39$.

Barley, L. \& GibBs, A. J. (1962). Cultural characteristics of Streptococcus pluton (White) and its differentiation from associated enterococci. J. gen. Microbiol. 28, 385 .

Foster, J. W., Hardwick, W. A. \& Guirard, B. (1950). Antisporulation factors in complex organic media. I. Growth and sporulation studies of Bacillus larvae. J. Bact. $59,463$.

Hrтснсоск, J. D. (1958). Comparative susceptibility of larvae of different stocks of honey bees to American foulbrood when reared by the same nurse bees. 10th int. Congr. Ent. (1956), 4, 1097.

Holst, E. C. (1946). Newer knowledge of American foulbrood. Glean. Bee Cult. 74, 138.

JAECKEL, S. (1930). Zur pathologischen Anatomie der Biene Apis mellifica L. während der metamorphose bei bösartiger Faulbrut. (Bacillus larvae White). Arch. Bienenk. 11, 41.

Kitaoka, S., Yajima, A. \& Azuma, R. (1959). Susceptibility of honey bee larvae to spores of Bacillus larvae, the cause of American foulbrood. Nat. Inst. anim. Hith (Japan) Bull. no. 37. 


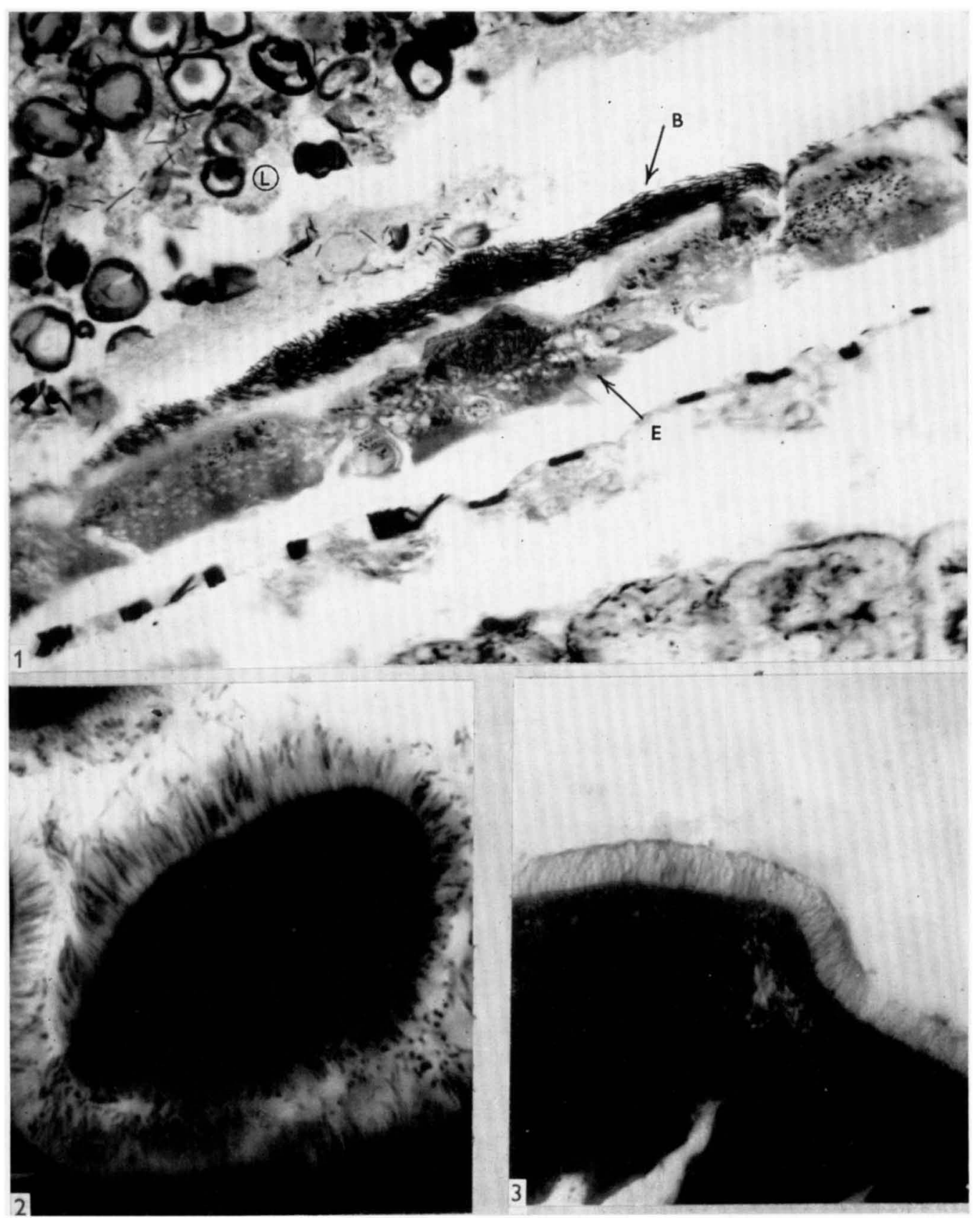



LochHead, A. G. (1933). Semi-solid medium for the cultivation of Bacillus larvae. Bee World, 14, 114.

LochHead, A. G. (1942). Growth factor requirements of Bacillus larvae White. J. Bact. 44, 185.

MaAssen, A. (1908). Zur Aetiologie der sogenannten Faulbrut der Honigbiene. Arb. biol. Abt. (Anst.-Reichsanst.), Berl. 6, 53.

Smith, R. L., Beck, J. V. \& Anderson, E. J. (1949). The effect of pollen on the sporulation of Bacillus larvae White. J. Bact. 57, 212.

Sturtevant, A. P. (1932). Relation of commercial honey to the spread of American foulbrood. J. Agric. Res. 45, 257.

TARR, H. L. A. (1937). Studies on American foulbrood of bees. I. The relative pathogenicity of vegetative cells and endospores of Bacillus larvae for the brood of the bees. Ann. appl. Biol. 24, 377.

TARR, H. L. A. (1937). Studies on American foulbrood of bees. II. The germination of the endospores of Bacillus larvae in media containing embryonic tissue. Ann. appl. Biol. 25,633 .

White, G. F. (1907). The cause of American foulbrood. Circ. U.S. Bur. Ent. no. 94.

White, G. F. (1920). American foulbrood. Bull. U.S. Dep. Agric. no. 809.

Woodrow, A. W. (1942). Susceptibility of honey bee larvae to individual inoculations with spores of Bacillus larvae. J. econ. Ent. 35, 892.

Woodrow, A. W. \& Holst, E. C. (1942). The mechanism of colony resistance to American foulbrood. J. econ. Ent. 35, 327.

Wynne, E. S. (1948). Physiological studies on spore formation in Clostridium botulinum. J. infect. Dis. 83, 243.

\section{EXPLANATION OF PLATE}

Fig. 1. Bacillus larvae in the mid-gut of a 4- to 5-day honeybee larva. $(\times 400) L=$. lumen of gut, $\mathrm{B}=$ rods of Bacillus larvae; $\mathbf{E}=$ gut epithelium.

Fig. 2. Bacillus larvae among the hairs of the brush border of an epithelial cell. $(\times 1000)$.

Fig. 3. Brush border of a normal epithelial cell. 